\title{
Assessment of the Use of Electronic Media by Farmers in Ushongo Local Government Area of Benue State, Nigeria
}

\author{
OTENE, V. A., CHIA, J. I. and IJUH, R. H.
}

Department of Agric. Extension and Communication, University of Agriculture, Makurdi

Article No.: 080118108

Type: Research

DOI: 10.15580/GJAS.2018.8.080118108

Submitted: 01/08/2018

Accepted: 08/08/2018

Published: $27 / 08 / 2018$

${ }^{*}$ Corresponding Author

Victor Akwu Otene

E-mail: otlevite@yahoo.com

Phone: +2348069338509
This study was carried out to assess the use of electronic media by farmers in Ushongo Local Government Area of Benue State, Nigeria. One hundred and twenty respondents were selected for the study using purposive and random sampling techniques. Data were collected using a structured questionnaire. The result revealed that the electronic media most accessed by the respondents were radio, mobile phones and television. The level of use of electronic media was generally low. Usage of electronic media was affected by low income, poor power supply, transmission problems and high cost of electronic media. The income of the respondents significantly affected their level of use of electronic media. It was therefore recommended that agricultural message by conveyed to farmers via the electronic media most assessed, while power supply and transmission signals are improve in the study area.

\section{Keywords:}

Assessment, Use, Electronic media,

Farmers, Ushongo 


\section{INTRODUCTION}

Agriculture plays an important role in the development of the Nigerian economy, household's income generation and food security in the sense that it provides food, feed, cash crops and diverse raw materials for agro-allied industries (Shuwa et al., 2014). Improving agricultural performance is the most powerful tool we have available to reduce global poverty and hunger (Mahzer et al., 2003).

Information has a significant role to play in increasing agricultural production (Otene et al., 2015). Farmers need to be aware of recent trends in agricultural production, and innovations that would increase their productivity (Ghazanfar et al., 2010). Information and communication technology (ICTs) has become an increasingly powerful tool for improving the delivery of extension services and enhancing agricultural development (Okwu et al., 2007).

What is known today as electronic media has resulted from a series of innovative technological inventions which have developed over centuries (Ravi, 2013). The electronic media in today's world has been described as a combination of content, comprising a scientific and artistic ensemble of music, film, TV, radio, video, publications, advertisement, and electronic games (Pur and Gwary, 2008). These are channels that could be used to effectively communicate with farmers. Electronic media can only be useful to farmers if they have access to, and are able to use them (Ewuola et al., 2010).

Farmers in Ushongo Local Government Area of Benue State would also need agricultural information, as other farmers (Otene et al., 2015). Adoption of the use of electronic media by agricultural extension agencies will facilitate the flow of information to the farmers. The ability of the farmers to access and use these electronic media is key to the adoption of its use (Ani et al., 2015). This research was therefore designed to assess the use of electronic media by farmers in Ushongo local Government Area, bearing in mind the use of these media to communicate agricultural information to the farmers. The specific objectives of the study were to:

1. determine the socio-economic characteristics of respondents;

2. determine the famer's accessibility to electronic media;

3. determine the level of use of electronic media in the study area; and

4. identify the problems associated with the use of electronic media by the farmers in the study area.

The following hypothesis was stated and tested:

The socio-economic characteristics of the farmers do not have any significant effect on their level of use of electronic media.

\section{MATERIALS AND METHODS}

\section{The Study Area}

The study area for this research is Ushongo Local Government Area. Ushongo is a Local Government Area of Benue State, Nigeria. Its headquarters is in the town of Lessel. It has a land mass of about $1,228 \mathrm{~km}^{2}$ and a population of about 188,341 persons (NPC, 2006). The postal code of the area is 982 .

Ushongo Local Government Area is dominated by undulating terrain with much of the area being below $183 \mathrm{~m}(600 \mathrm{ft})$ above the sea level. The climate is tropical with the mean annual rainfall of between 1,200 and 2,000 mm averaging seven months in the year, while the mean annual temperature is $32.5^{\circ} \mathrm{C}$. The wet season is from April to October or November while the dry season is November to March, (Wikipedia, 2017).

Agriculture is the mainstay of the people with arable land for sheep, goats and cattle rearing. Over 80 percent of the population are directly engaged in the peasant farming of virtually all major food crops, with concentration on rice, sweet potatoes, cassava, sorghum, citrus, spices, pepper, groundnut and bambara nuts. The study area is endowed with mineral deposits such as barites, kaoline and iron ores.

\section{Method of Collection of Data}

Primary data were used for the study, collected using a well-structured questionnaire. The questionnaire comprised of four (4) sections, A to D. Section A dealt with Socioeconomic Characteristics of the respondents, section $B$ determined the farmers accessibility to electronic media, section $\mathrm{C}$ determined the level of use of electronic media, while section $D$ identified the problems associated with uses of electronic media

\section{Sampling Procedures and Sample Size}

Farmers in Ushongo Local Government Area of Benue State formed the population of the study. Out of the eleven council wards in Ushongo Local Government Area of Benue State, six (6) were purposively selected based on their relatively high level of participation in their use of electronic media for the adoption of agricultural innovations. The selected council wards were Mbaanyam, Mbaaka, Mbatikyese, Mbavende, Mbayegh and Utange. Ten percent of farmers in each of the council ward were selected for the study. The population of the respondents was obtained following a reconnaissance survey (Mbaanyam (303), Mbaaka (195), Mbatikyese (204), Mbavende (201), Mbayegh (147) and Utange (153)). The sample size was therefore 120 respondents.

\section{Measurement of Variables}

\section{Dependent Variable}

The dependent variable in this study is the level of use of electronic media. This was measured using a Likert- 
type scale ranging from low to high. Respondents that indicated their level of use of electronic media to be either "medium" or "high" were classified as having a high level of use of electronic media, while those that indicated "low" were classified as having a low level of use of electronic media.

\section{Independent Variables}

1. Age was measured as the chronological age of the respondents in years.

2. Marital status was measured as a dummy variable; $1=$ Married, $0=$ Single.

3. Education was measured as a dummy variable; $1=$ formal education, $0=$ No formal education.

4. Farm size is the size of farm land cultivated by the respondents, measured in Hectares.

5. Household size was measured as the number of persons living in the house of the respondent at the time of data collection.

6. Income is the money that respondents make from their farming enterprise in Naira.

\section{Data Collection and Statistical Analysis}

Data for the study were analyzed sing descriptive and inferential statistics. Descriptive statistics as frequencies and percentages were used to analyze the objectives, while the hypothesis was tested using Logistic regression. The model for the regression is of the form:

$Y=\beta_{0}+\beta_{1} X_{1}+\beta_{2} X_{2}+\beta_{3} X_{3}+\beta_{4} X_{4}+\beta_{5} X_{5}+\beta_{6} X_{6}+v_{i}$

Where $Y=$ Probability of level of use of electronic media ( $1=$ High, $0=$ Low)

$X_{1}=$ Age, $X_{2}=$ Marital Status, $X_{3}=$ Education, $X_{4}=$ Household size, $X_{5}=$ Farm size, $X_{6}=$ Income, $v_{i}=$ Error term

\section{RESULT AND DISCUSSION}

\section{Socioeconomic Characteristics of the Respondents.}

The result of the socioeconomic characteristics of the respondents is presented in Table 1. Research finding also reveal that majority $(42.7 \%)$ of the respondents were aged between 31-40 years. This implies that most of the respondents in the study area were in their active years and provide labour needed to augment agricultural development in the study area.

\begin{tabular}{|c|c|c|}
\hline $\begin{array}{l}\text { Socioeconomic } \\
\text { characteristics }\end{array}$ & Frequency & Percentage \\
\hline \multicolumn{3}{|l|}{ Age (years) } \\
\hline$\leq 20$ & 4 & 3.4 \\
\hline $21-30$ & 29 & 24.8 \\
\hline $31-40$ & 50 & 42.7 \\
\hline $41-50$ & 30 & 26.6 \\
\hline $51-60$ & 4 & 3.4 \\
\hline \multirow{2}{*}{\multicolumn{3}{|c|}{ Marital Status }} \\
\hline & & \\
\hline Single & 25 & 21.4 \\
\hline \multirow{2}{*}{\multicolumn{3}{|c|}{ Level of Education }} \\
\hline & & \\
\hline Non-formal education & 8 & 6.8 \\
\hline Formal education & 112 & 93.2 \\
\hline \multicolumn{3}{|c|}{ Household Size (persons) } \\
\hline$\leq 5$ & 26 & 22.2 \\
\hline $6-10$ & 62 & 53.0 \\
\hline $11-15$ & 20 & 17.1 \\
\hline $16-20$ & 8 & 6.8 \\
\hline$\geq 21$ & 1 & 0.9 \\
\hline \multicolumn{3}{|l|}{ Farm Size (hectare) } \\
\hline$\leq 5$ & 51 & 43.6 \\
\hline $6-10$ & 52 & 44.4 \\
\hline $11-15$ & 12 & 10.3 \\
\hline$>15$ & 2 & 1.7 \\
\hline \multicolumn{3}{|l|}{ Annual Income (N) } \\
\hline$\leq 50,000$ & 5 & 6.8 \\
\hline $51,000-100,000$ & 25 & 21.4 \\
\hline $101,000-150,000$ & 56 & 47.9 \\
\hline $151,000-200,000$ & 22 & 18.8 \\
\hline $201,000-250,000$ & 22 & 18.8 \\
\hline $251,000-300,000$ & 4 & 3.4 \\
\hline$\geq 300,000$ & 2 & 1.7 \\
\hline
\end{tabular}


With respect to marital status, most of the respondents $(78.6 \%)$ were married. This implies that most of the respondents in the study area were married, and have greater opportunity of having family labour which is an advantage to agricultural production. The result agrees with that of Otene et al. (2015), which revealed that most rural farmers in Nigeria are married.

Results on the level of education of the farmers revealed that $93.2 \%$ of the respondents had formal education. The respondents in the study area were therefore educated, and could use electronic media to access information. This finding is in contrast to that of Olojede et al., 2013.

With consideration to household size, most of the respondents $(53.0 \%)$ had household size of 6-10 persons. This large household size gives the respondents the opportunity of utilizing family labour, leading to profit maximization in agricultural ventures. It also increases the chances of having access to electronic media, as members of the family could have personal units that would grant them access to the media.

With respect to farm size, Majority $(63.0 \%)$ of the respondents had farm size of 6-10 hectares. This implies that most of the farmers were operating on commercial level, and information would be necessary for them to optimize their production. As presented in Table 1, most $(47.9 \%)$ of the respondents had annual income between $\mathrm{N101}, 000$ and $\mathrm{N150}, 000$. This shows that most farmers in the study area were small income earners. This low income status might reduce their ability to procure capital intensive technologies, and discourage them from purchasing gadgets that would grant them access to electronic information.

\section{Accessibility to Electronic Media}

The respondents' accessibility to electronic media presented in Table 2. Research findings reveal that the most accessed media by the respondents were radio (99.1\%), mobile phones (99.1\%) and television $(98.3 \%)$. From this finding, it can be deduced that radio, mobile phones and television are the frequently used electronic media in the study area. Communication with the farmers could be initiated using these media. Inayatullah et al. (2014) reported that the mass media most accessed by farmers in Jaffarabad District of Balochistan, Pakistan were television and radio.

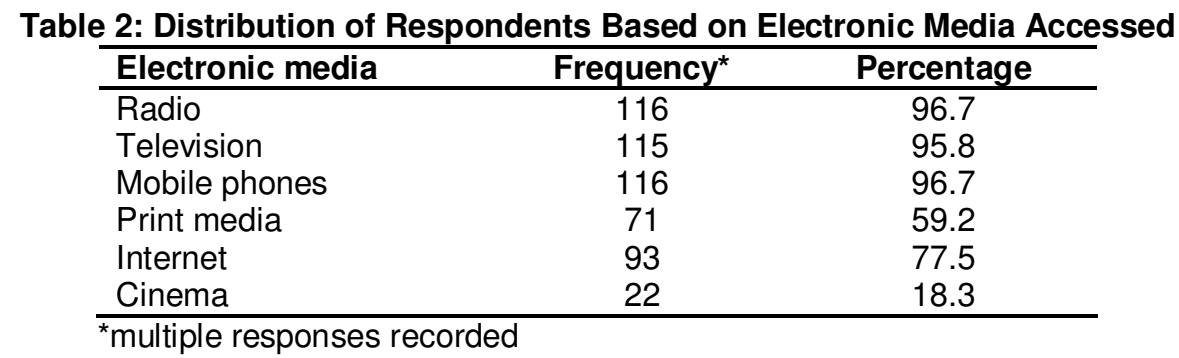

\section{Level of use of Electronic Media}

The level of use of electronic media by respondents is presented in Table 3. Majority of the respondents $(52.5 \%)$ indicated that they had low level of use of electronic media. This low level of use could discourage the communication of agricultural information to the farmers using electronic media. Ani et al. (2015) also reported that farmers in Ikwere Local Government Area of Rivers State, Nigeria have low level of usage of mass media.

Table 3: Level of use of Mass Media $(n=120)$

\begin{tabular}{lcc}
\hline Level of use & Frequency & Percentage \\
\hline Low & 63 & 52.5 \\
Medium & 37 & 30.1 \\
High & 20 & 16.7 \\
\hline
\end{tabular}

\section{Problems Associated with the use of Electronic Media}

The problems associated with the use of electronic media is presented in Table 4. The major problems faced by the respondents are low income (92.5\%), poor power supply $(89.2 \%)$, transmission problems $(88.3 \%)$ and high cost of electronic media $(85.8 \%)$. Providing solution to these problems would facilitate the use of electronic media to communicate with the farmers. Ani and Baba (2009) also identified poor power supply and low income as constraints to the use of electronic media by farmers in Northern Taraba State, Nigeria. 
Table 4. Problems Associated with the use of Electronic Media

\begin{tabular}{lcc}
\hline Problem & Frequency & Percentage \\
\hline Illiteracy & 28 & 23.3 \\
Low income & 111 & 92.5 \\
High cost of electronic media & 103 & 85.8 \\
Poor power supply & 107 & 89.2 \\
Lack of audience feed back & 74 & 61.7 \\
Transmission problem & 106 & 88.3 \\
Inaccurate information & 94 & 78.3 \\
Poorly planned programmes & 86 & 71.7 \\
\hline
\end{tabular}

Table 5: Effect of the Socioeconomic Characteristics of Respondents on their Level of Electronic Media

\begin{tabular}{lccccc}
\multicolumn{7}{c}{ Use } \\
\hline Socio-economic Characteristics & Coefficient & Standard error & Wald & Sig & Exp(B) \\
\hline Age & 0.022 & 0.041 & 0.306 & 0.580 & 1.023 \\
Marital status & 0.053 & 0.603 & 0.008 & 0.930 & 1.054 \\
House hold size & -0.060 & 0.057 & 1.110 & 0.292 & 0.942 \\
Education & -0.039 & 0.046 & 0.709 & 0.400 & 1.040 \\
Farm size & -0.046 & 0.061 & 0.576 & 0.448 & 0.955 \\
Income & 0.300 & 0.000 & 6.720 & $0.010^{*}$ & 1.000 \\
Constant & -2.131 & 1.163 & 3.359 & 0.067 & 0.119 \\
\hline
\end{tabular}

${ }^{*}$ indicates significant at $1 \%$ level of probability

$X^{2}=13.35$. Sig. $=0.064 ;$ log likelihood $=127.67 ;$ Nagelkerke $R^{2}=0.1541$

Effect of the Socioeconomic Characteristics of Respondents on the Level of Electronic Media Use

The result of the logistic regression carried out to determine the effect of the socioeconomic characteristics of the respondents on their level of use of electronic media is presented in Table 5. It was found out that only one of the socioeconomic characteristics significantly affected the level of use of electronic media; income.

Income had a positive coefficient $(\beta=0.300)$ and was significant at $1 \%($ Sig. $=0.010)$. This means that respondents with higher income will have a greater probability to have a high level of use of electronic media. This is logical, as farmers with higher income will have money to purchase gadgets that will grant them access to information through electronic media. Ani and Baba (2009) also found income to affect the usage of mass media by farmers in Northern Taraba State, Nigeria.

The chi-square value of the logit regression model is 13.352 , and was not statistically significant $($ sig. $=0.064)$. This implies that the socioeconomic characteristics of the respondents do not have any significant effect on their level of use of electronic media. The Nagelkerke $R^{2}$ for the regression is 0.154 , indicating that the variables tested accounted for only $15.4 \%$ of the variations in the dependent variable. The null hypothesis for the study is therefore accepted.

\section{CONCLUSION AND RECOMMENDATIONS}

The findings revealed a population that were in their active age, predominantly married, educated and large household sizes. The respondents had small farms and earned low annual incomes. The most accessed electronic media by respondents were radio, mobile phones and television. Most of the respondents had low level of use of electronic media, and the problems associated with the use of electronic media we low income, poor power supply, transmission problems and high cost of electronic media. Income was the only socioeconomic characteristic of the respondents that significantly affected their level of use of electronic media.

Based on the findings of the research, the following recommendations were made;

1. Agricultural information should be conveyed to the farmers through the most accessed electronic media, as radio, mobile phones and television.

2. Farmers in Ushongo should be taught to use electronic media by extension agents, considering the low level of use of electronic media.

3. Power supply to the study area should be improved to encourage the use of electronic media.

\section{REFERENCES}

Ani, A. O. and Baba, S. A. (2009). Utilization of selected electronic mass media as sources of agricultural information by farmers in Northern Taraba State, Nigeria. Tropical Agricultural Research and Extension, 12(1); 17-22

Ani, A. O., Umunakwe, P .C., Ejiogu-Okereke, E. N., Nwakwasi, R. N. and Aja, A.O. (2015). Utilization of mass media among farmers in lkwere Local Government Area of Rivers State, Nigeria. IOSR Journal of Agriculture and Veterinary Science (IOSR-JAVS), 8(7); 41-47 
Ewuola, S. O., Ogunsumi, L. O. and Augustu, E.O. (2010). Assessment of extension media use among youth farmers in Oyo and Ondo states, Nigeria. American Journal of Social and Management Sciences, 1(2); 181-185

Ghazanfar, A. K., Sher, M., Khalid, M. C. and Muhammad, A. K. (2010). Present status and future preferences of electronic media as agricultural information sources by the farmers. Pakistan Journal of Agricultural Science, 47(2); 166-172

Inayatullah, M., Khalid, N. P., Rafique, A. C., Abdul, Latif, B. and Aijaz, A. K. (2014). Role of Mass Media in Dissemination of Agricultural Technology among the Farmers of Jaffarabad District of Balochistan. Journal of Basic and Applied Sciences, 10; 525-531

Mazher, A., Sheikh, A.D., Sher, M. and Muhammad, A. (2003). Role of electronic media in the adoption of agricultural technologies by farmers in the Central Punjab-Pakistan. International Journal of Agriculture and Biology, 5(1); 22-25

NPC (2006). Nigeria National Population Census Report

Okwu, O. J., Kuku, A. A. and Aba, J. I. (2007). An assessment of use of radio in agricultural information dissemination: a case study of radio Benue in Nigeria. African Journal of Agricultural Research, 2 (1); 14-18
Olojede, A. A., Adekunle, A. A. and Samuel, E. A. (2013). Analysis of rural literacy as a panacea for socio-economy development of Nigeria. International Journal of Sociology and Anthropology, 5(9); 381-390.

Otene, V. A., Okwu, O. J. and Gwaza, S. S. (2015). Barriers to the use of radio as a channel of agricultural information by farmers in Ushongo Local Government Area of Benue State, Nigeria. Journal of Agricultural and Food Information, 16(4); 326-336

Pur, J. T. and. Gwary, M. M. (2008). Determinants of effectiveness of electronic media in agricultural information delivery in Yola North Local Government Area of Adamawa State, Nigeria. PAT $4(1) ; 21-27$

Ravi, B. K. (2013). Electronic media and agriculture promotion - an explorative study in Karnataka. Retrieved from http://www.savap.org.pk/journals/ARInt./Vol.4(4)/2 013 (4.4-33).pdf

Shuwa, M.I., Shettima, L., Makinta, B.G., and Kyari A. (2015). Impact of mass media on farmers' agricultural production, case study of Borno State, Agricultural Development Programme, Academia Journal of Scientific Research, 3(1); 8-14

Wikipedia. (2015). Ushongo. Retrieved from https://en.m.wikipedia.org/wiki/Ushongo 